\title{
ASSESSMENT AND MAPPING OF THE AGRO-ECOLOGICAL RISK IN THE MINA PLAIN (NORTHWESTERN ALGERIA): SOIL SALINITY AND IRRIGATION WATER QUALITY
}

\author{
IBRAHIM BERKANE $\triangle^{1}$, HOUARI BOULENOUAR ${ }^{1}$, YOUCEF BEKHADDA ${ }^{2}$, FARID GACEM ${ }^{1,2}$, ABDELKADER \\ DOUAOUI ${ }^{3}$, MOHAMED LARID ${ }^{1}$ KHELLOUFI BENABDELI $^{4}$
}

\author{
${ }^{1}$ Laboratory: Biodiversity, Water and Soil Conservation, University of Mostaganem, Mostaganem 27000, Algeria; e-mail: berbrahim@gmail.com, boulenouar- \\ houari21@gmail.com, laridsid@yahoo.fr \\ ${ }^{2}$ INSID - National Institute of soils, Irrigation and Drainage, Relizane 48000, Algeria; e-mail: youcefagro1@gmail.com \\ ${ }^{3}$ University Center of Tipaza, Laboratory Management and Valorization of Agriculture and Aquatic Ecosystems (LMVAAE), Tipaza 42022, Algeria; e-mail: \\ abdouaoui@yahoo.fr \\ ${ }^{4}$ Laboratory: Geo-Environment and Spatial Development, University of Mascara, Mascara 29000, Algeria; e-mail: kbenabdeli@yahoo.fr
}

$\triangle$ Corresponding author

Received: 9 May 2020 / Accepted: 13 August 2020

Abstract

Berkane I., Boulenouar H., Bekhadda Y., Gacem F., Douaoui A., Larid M., Benabdeli K.: Assessment and mapping of the agro-ecological risk in the Mina plain (northwestern Algeria): Soil salinity and irrigation water quality. Ekológia (Bratislava), Vol. 40, No. 3, p. 201-211, 2021.

\begin{abstract}
The objective of this study is to contribute in assessing and mapping of the salinity risks level of soil and groundwater for irrigation in the Mina plain. The experimentation was carried out on a surface area of $4000 \mathrm{ha}$. Electromagnetic conductivity (EM) measurements and soil and well water samples were taken and analysed. The results showed an important spatial variability of the electrical conductivity (EC) of saturated paste extracts (ECe), which varied between 1.35 and $28.8 \mathrm{dS} / \mathrm{m}$. The isovalues map of ECe was estimated by the regression equation and interpolated by the ordinary kriging (OK) method which showed that the area of saline soils (ECe $>4 \mathrm{dS} / \mathrm{m}$ ) represented $90 \%$ of the study area. The results also showed poor to unsuitable well water quality. To find the risk of salinity and sodium, the water points were classified as C3S3 (2.5\%), C4S2 (5\%), C4S3 (30\%) and C4S4 (62.5\%). Spatial distribution maps of total dissolved solids (TDS), electrical conductivity of water (ECw) and sodium adsorption ratio (SAR) interpolated by inverse distance weighting (IDW) showed too high risk levels of ECw $(>5000 \mu \mathrm{S} / \mathrm{cm})$ and TDS $(>3000 \mathrm{mg} / \mathrm{l})$ occupying a large wellfield (70\%); with regard to SAR (>18), 36\% of the groundwater had a high risk of sodium. These results showed that the choice of tolerant crops, redevelopment of drainage systems and irrigation with less saline water should be designed for the sustainability of soil productivity and agro-ecosystems.
\end{abstract}

Key words: map soil salinity, water salinity hazard, SAR, kriging, IDW, Mina plain, Algeria.

\section{Introduction}

Soil salinisation is a major global problem which has already affected at least 400 million ha and seriously threatened an equivalent area, most of which is located in arid and semi-arid zones (Legros, 2009; FAO, 2006). Soil salinisation has two origins - one is natural and affects $80 \%$ of salinised land, known as primary salinisation, and the second is anthropogenic, mainly due to irrigation, and is called secondary salinisation (FAO, 2006).

In Algeria, saline soils occupy a large area, that is, 3.2 million ha of the total surface area, with varying degrees of severity due to the salinisation process. This effect is more marked by high temperatures during the year, restricted drainage and insufficient rainfall $(<450 \mathrm{~mm})$ to leach soluble salts from the soil (Szabolcs, 1989; Djili, 2000). Nearly $10 \%-15 \%$ of the irrigated land is af- fected by these problems; these salinised lands will be difficult to recover (Halitim, 1985; Daoud, Halitim, 1994). The Mina plain is particularly affected by the problem of salinisation; nearly $70 \%$ of the soil of the irrigated perimeter is affected by salinity. This salinisation is primary (presence of salts in the soil or water table) or secondary, mainly due to irrigation, which affects $20 \%-50 \%$ of the irrigated land in Algeria (Douaoui, Hartani, 2007; INSID, 2008). Today, the plain is subjected to agro-environmental issues; soil salinity and poor quality of groundwater for irrigation have become the major problems for irrigated soils.

The knowledge of the current risk level of salinity in agricultural land and the quality of groundwater used for irrigation purposes for the different classes of agricultural land use can allow good management of agricultural land through the control of irrigation, drainage and the improvement of agricultural productivity and contribute to the sustainability of irrigated agriculture.

(c) The Author(s) 2021. This is an open access article distributed under the terms of the CC BY-NC-ND license.

https://content.sciendo.com/view/journals/eko/eko-overview.xml 


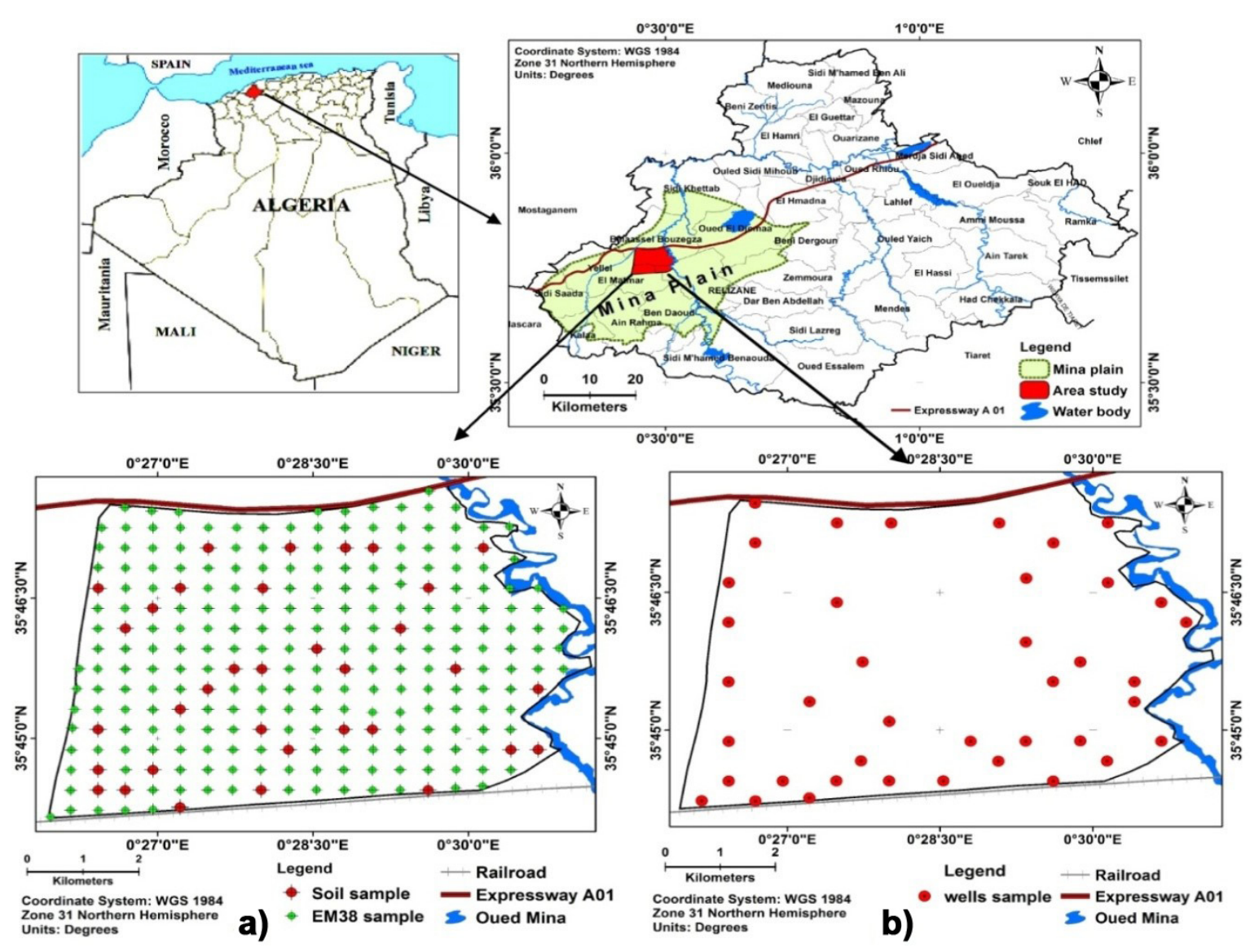

Fig. 1. Location of the study area. a) Soil and EM38 sample; b) well sample

\section{Material and methods}

\section{Description of study area}

The study area is part of the Mina plain, which is located in the northwest of Algeria; it is an agricultural area of 4000 ha. The geographical coordinates of the area, in longitude/latitude in datum of World Geodetic System, 1984 (WGS84), are between the longitudes $0^{\circ} 26^{\prime} 1.60^{\prime \prime} \mathrm{E}$ and $0^{\circ} 31^{\prime} 9.96^{\prime \prime} \mathrm{E}$ and the latitudes $35^{\circ} 44^{\prime} 8.06^{\prime \prime} \mathrm{N}$ and $35^{\circ} 47^{\prime} 42.59^{\prime \prime} \mathrm{N}$ (Fig. 1). With a semi-arid climate characterised by very hot summers and low annual rainfall of $287 \mathrm{~mm}$ and very high annual evapotranspiration of $1520 \mathrm{~mm}$ (average for the period 1987-2019), the study area has a rainy period from October to the end of March and a dry period during the rest of the year (from April to mid-October).

\section{Geomorphology}

The study area is located in a syncline or depression surrounded by low elevation plateaus with an average altitude of $80 \mathrm{~m}$ and less than $3 \%$ of the slope dominated to the south, east and west by mountainous massifs filled with Quaternary alluvium and crossed by the bed of the Mina wadi (Fig. 2). From a geological point of view, the basic substratum in the alluvial valley of the Mina wadi is a clay formation on which recent alluvial sediments have been deposited, often with saline characteristics (ANRH, 2003). The soils are alluvial deposits whose original material was more or less saline. Saliferous formations (Triassic, Miocene, Helvetian, Sahelian) that outcrop in the Ouarsenis are the main providers (ANRH, 2003). They are characterised by fine-structured soils (clay-silt), potentially salinable, with the presence of an appreciable level of limestone (Gaucher, Burdin, 1974; ANRH, 2003).

\section{Hydrology and hydrogeology}

The hydrographic network consists of the Mina wadi which drains the reliefs of the Ouarsenis. From a hydrogeological point of view, the rivers carry all the brackish water due to the existence of saline springs and the leaching of the upstream Triassic and Miocene saline soils which infiltrate and accumulate in the sandy layers and are interlayered between the salty clays and form aquifers that flow underground, disperse and come to settle in small, impermeable depressions (ANRH, 2003)

\section{Methodological approach}

The objective of this study is to assess and map the level of the soil salinity and the quality of groundwater used for irrigation in 
Table 1. Physicochemical parameters of soil and Water and their Methods Used.

\begin{tabular}{|c|c|c|c|c|}
\hline & Parameters & Methods & Parameters & Methods \\
\hline \multirow{4}{*}{ Soil } & Granulometry & Robinson's pipette method & Humidity (\%) & Oven Drying Method \\
\hline & Saturated paste extract & $\begin{array}{l}\text { US Salinity Laboratory } \\
\text { (Richards, 1954) }\end{array}$ & Total limestone (\%) & Bernard calcimeter \\
\hline & $\begin{array}{l}\text { potential hydrogen } \\
(\mathrm{pH})\end{array}$ & $\begin{array}{l}\text { pH-meter } \\
\text { (ratio soil - water } 1 / 2,5 \text { ) }\end{array}$ & Organic matter (\%) & $\begin{array}{l}\text { Ane method - The formula } \\
\left(\mathrm{OM} \%=\mathrm{C}^{\star} 1,72\right)\end{array}$ \\
\hline & $\begin{array}{l}\text { electrical conductivity } \\
\text { (ECe) in } \mathrm{dS} / \mathrm{m} \text { at } 25^{\circ} \mathrm{C}\end{array}$ & $\begin{array}{l}\text { Systronic Conductivity } \\
\text { Meter/ }\end{array}$ & & \\
\hline \multirow{4}{*}{ water } & $\begin{array}{l}\text { potential hydrogen } \\
\left(\mathrm{P}^{\mathrm{H}}\right)\end{array}$ & $\begin{array}{l}\text { Systronics } \mathrm{pH} \text { meter/ } \\
\mathrm{P}^{\mathrm{H}} \text { meter portable }\end{array}$ & Chloride $\left(\mathrm{Cl}^{-}\right)$ & Argentometric titration \\
\hline & $\begin{array}{l}\text { Electrical conductivity } \\
\text { (ECw) }\end{array}$ & $\begin{array}{l}\text { Systronic Conductivity Meter/ } \\
\text { portable conductivity meter }\end{array}$ & $\begin{array}{l}\text { Bicarbonate }\left(\mathrm{HCO}_{3}^{-}\right) \text {and } \\
\text { carbonate }\left(\mathrm{CO}_{3}^{2-)}\right.\end{array}$ & Titration with $\mathrm{H}_{2} \mathrm{SO}_{4}$ \\
\hline & $\begin{array}{l}\text { Calcium , magnesium, sodium } \\
\text { and potassium } \\
\left(\mathrm{Ca}^{++}, \mathrm{Mg}^{++}, \mathrm{Na}^{+} \mathrm{K}^{+}\right)\end{array}$ & $\begin{array}{l}\text { Atomic absorption } \\
\text { spectrometer }\end{array}$ & $\begin{array}{l}\text { Total dissolved solids } \\
\text { (TDS) Hardness Total }\end{array}$ & calculation \\
\hline & Sulfate $\left(\mathrm{SO}_{4}^{-2}\right)$ & Turbidimetric Method & & \\
\hline
\end{tabular}

relation to the different classes of agricultural land use. This approach is based on measurement of electromagnetic conductivity (EM) by an EM meter (EM38, Geonics LTD), sampling of soil and well water, statistical data processing and calibration of EM measurements, and finally mapping of agricultural land use and salinity risk levels (soil and water).

\section{Measurement of EM38 and collection of soil samples}

Using a Garmin Global Positioning System (GPS) and the EM38, we measured the conductivity of 260 points (Fig. 1a) in a horizontal position (0-75 $\mathrm{cm}$ [EMh]) and in a vertical position (0$150 \mathrm{~cm}$ [EMv]) (Job et al., 1990). The measurement and sampling campaign was carried out during the period from April to June 2019. The use of this technique in the spatial characterisation of salinity is widely developed in precision agriculture (Cameron et al., 1981; Lesch et al., 1995; Triantafilis et al., 2001). To calibrate the EM38 measurement data, we conducted 34 soil profiles at a depth of $75 \mathrm{~cm}$ and in such a way as to spatially represent the entire study area. This depth generally represents the depth of the root zone of most crops in the studied area. The soil samples were coded and placed in well-sealed plastic bags and processed for analysis. Due to the depth of investigation of EM38 up to 1.50 $\mathrm{m}$, only the EMh measurements were considered. Moreover, the best time to carry out EM38 measurements and sampling is after the rainy period or irrigation, so that it can homogenise soil water profiles (Job et al., 1990).

\section{Laboratory analysis}

Once the soil samples were dried, crushed and passed through 2-mm square mesh sieves, we proceeded to measure the parameters of the soil samples using the standard methods (Table 1). Forty water samples were taken from wells used for irrigation (Fig. 1b). The water samples were taken in plastic bottles and analysed within $24 \mathrm{~h}$. The $\mathrm{pH}$ and electrical conductivity (EC) of water were measured in situ at each sampling. The analyses of various physical and chemical parameters were carried out ac-

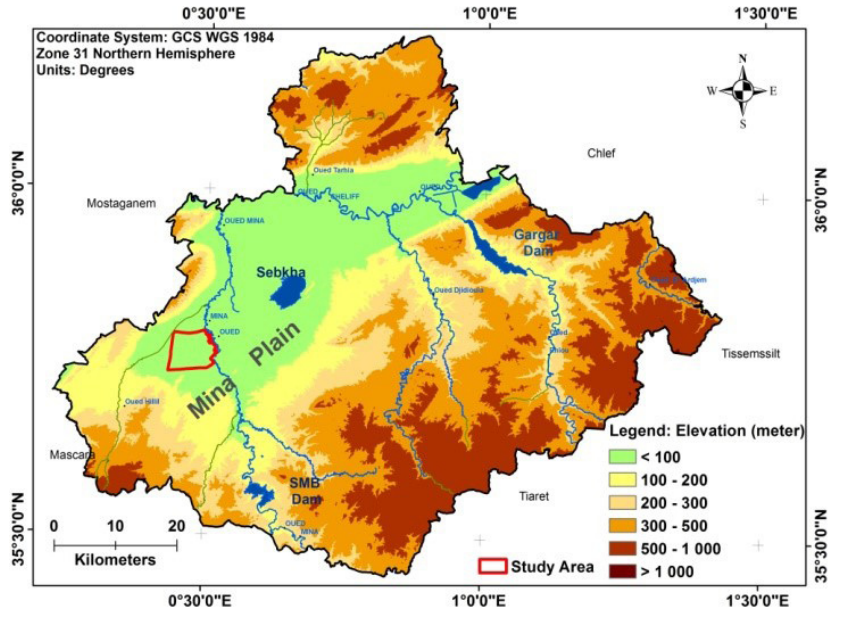

Fig. 2. Elevation map of Mina plain.

cording to the standard methods used by the American Public Health Association (APHA, 1995) (Table 1).

To assess the suitability of groundwater for irrigation purposes, the following irrigation quality parameters were calculated by the following equations:

Total dissolved solids:

$\operatorname{TDS}(\mathrm{mg} / \mathrm{l})=\mathrm{EC}(\mu \mathrm{S} / \mathrm{cm})^{\star} 0.64$ (Brown et al., 1970),

Hardness total:

$(\mathrm{TH} ; \mathrm{mg} / \mathrm{l})=\left(\mathrm{Ca}^{2+}+\mathrm{Mg}^{2+}\right)^{\star 50}(\mathrm{Hem}, 1985)$,

Sodium adsorption ratio:

$(\mathrm{SAR})=\mathrm{Na}+/\left[\left(\mathrm{Ca}^{2+}+\mathrm{Mg}^{2+}\right) / 2\right]^{1 / 2}$ (Richards, 1954),

Percentage of sodium:

$\mathrm{Na} \%=\left[(\mathrm{Na}++\mathrm{K}+)^{*} 100\right] /[(\mathrm{Ca} 2++\mathrm{Mg} 2++\mathrm{Na}++\mathrm{K}+)]($ Wilcox, 1955),

Residual sodium bicarbonate:

$(\mathrm{RSC})=\left(\mathrm{CO}_{3}{ }^{2-}+\mathrm{HCO}_{3}^{-}\right)-\left(\mathrm{Ca}^{2+}+\mathrm{Mg}^{2+}\right)($ Eaton, 1950), 
Table 2. Statistical of various parameters of soil in the study area.

\begin{tabular}{|l|c|c|c|c|c|c|c|c|c|c|}
\hline $\begin{array}{l}\text { Statistical } \\
\text { parameters }\end{array}$ & EMh & EMv & $\begin{array}{c}\text { ECe } \\
\left(\mathbf{d S . m ^ { - 1 } )}\right.\end{array}$ & $\mathbf{p H}$ & $\begin{array}{c}\text { Organic } \\
\text { Matter } \\
(\%)\end{array}$ & $\begin{array}{c}\text { Total } \\
\text { Limestone } \\
(\%)\end{array}$ & $\begin{array}{c}\text { Humidity } \\
(\mathbf{\%})\end{array}$ & Clay (\%) & Silt (\%) & Sand (\%) \\
\hline Number & 34 & 34 & 1.35 & 34 & 34 & 34 & 34 & 34 & 34 & 34 \\
\hline Min. & 30.00 & 44.00 & 28.42 & 5.86 & 1.05 & 13.02 & 3.61 & 10.32 & 16.00 & 9.98 \\
\hline Max. & 655.00 & 779.00 & 12.06 & 8.47 & 4.38 & 23.48 & 36.78 & 56.65 & 41.50 & 52.65 \\
\hline Average & 280.76 & 374.88 & 7.60 & 8.06 & 2.69 & 19.41 & 19.22 & 37.95 & 28.75 & 33.30 \\
\hline Std.Dev. & 192.92 & 245.86 & 57.80 & 0.42 & 0.89 & 2.24 & 9.44 & 11.39 & 6.70 & 11.59 \\
\hline CV\% & 68.71 & 65.58 & 63.02 & 5.22 & 32.99 & 11.54 & 49.12 & 30.01 & 23.30 & 34.80 \\
\hline
\end{tabular}

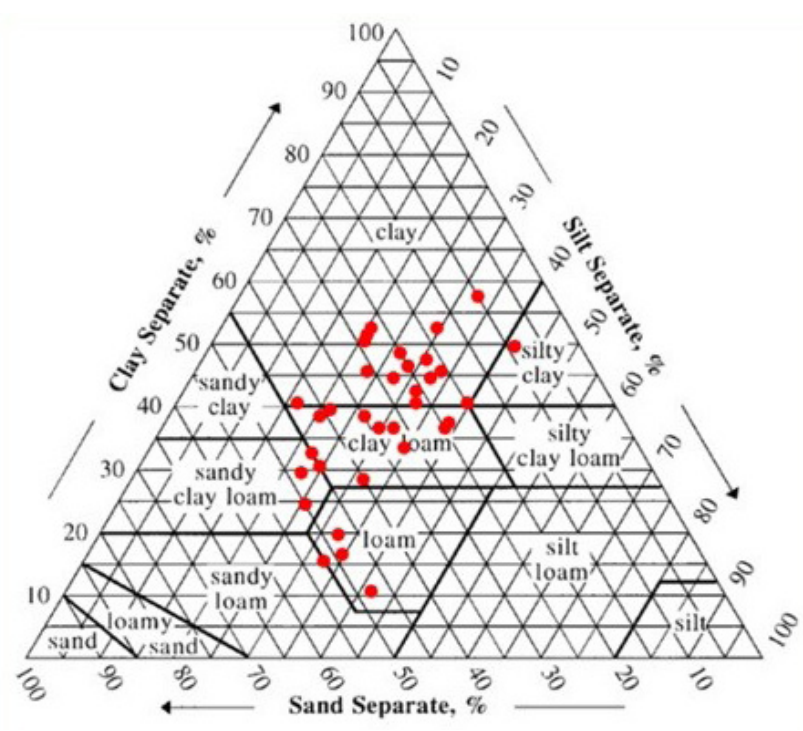

Fig. 3. The texture triangle of soil samples.

Permeability index:

$(\mathrm{PI})=\mathrm{Na}+\left[\left(\mathrm{HCO}_{3}^{-*} 100\right)\right]^{1 / 2} / \mathrm{Ca}^{2+}+\mathrm{Mg}^{2+}+\mathrm{Na}^{+}$(Doneen, 1964). All ions are expressed in meq/l.

\section{Statistical analysis}

Univariate and multivariate statistical analyses of the soil and water sample parameters were performed using IBM SPSS Statistics Base 22.0 software with Excel Microsoft Office 2007. For mapping, we used Mapinfo version 8.0 and ArcGIS version 10.3 .

\section{Spatial analysis}

For the spatial prediction and mapping of the risk level of soil salinity and groundwater quality, we used two spatial interpolation methods using ArcGIS software (version 10.3). The first is ordinary kriging (KO) for soil, which consists of interpolating and mapping the results of calibrated data taken systematically and representing the distribution of soil salinity (Walter, 1990). For the mapping of groundwater parameters (EC, TDS and SAR), the inverse distance weighting (IDW) interpolation method was applied for the analysis, considering all sampling points in the study area (Burrough, Mc Donell, 1998).

The map of agricultural land use was developed from the observation made by the use of ENVI 5.3 software for a supervised classification of a Landsat 8 Satellite image (Oli Captor) of date 13 April 2018 provided by the United States Geological Survey (USGS) and Google Earth satellite images, as well as through surveys and field investigations to visualise the agrarian landscape that allows us to verify the data from the satellite imagery in the field.

\section{EM calibration equation}

The calibration allows transformation of the EMh measurements to the ECe values for the soil samples taken from 34 profiles. It is done by establishing simple linear regression equations. For the same soil depth, the correlation between the EM (ECa) values and the ECe gives an equation of the following type (Vlotman, 2000):

$\operatorname{ECe}(0-z \mathrm{~cm})= \pm \mathrm{c} \pm \mathbf{a}^{\star} \operatorname{ECa}(0-\mathrm{z} \mathrm{cm})$

where ECa $(0-\mathrm{z} \mathrm{cm})$ is the average apparent conductivity of the soil over a soil depth of $0-\mathrm{z} \mathrm{cm}(\mathrm{dS} / \mathrm{m})$; in our study, the EMh $(0-75 \mathrm{~cm})$,

ECe $(0-z \mathrm{~cm})$ is the EC (salinity) of the saturated paste extract from soil sampled at a depth of $0-\mathrm{z} \mathrm{cm}(\mathrm{dS} / \mathrm{m})$; same depth (0-75 $\mathrm{cm}$ ),

$\mathrm{a}$ is the slope of the relationship and $\mathrm{c}$ is a constant.

\section{Results and discussion}

\section{Assessment of soil salinity hazard}

The results show the average (ECe) of the soil samples ranged from 1.35 to $28.42 \mathrm{dS} / \mathrm{m}$ at an average of $12.06 \mathrm{dS} / \mathrm{m}$ with a high variability of $63 \%$ (Table 2).

The reliability of assay was assessed by the coefficient of variation (CV) values of the parameters studied (Table 2), which were very low for $\mathrm{pH}$ and total limestone (5.22 and $11.5 \%$, respectively). On the other hand, ECe and the measurements of EMh, EMv and moisture were the most dispersed soil variables, given the high CV values (50-69\%). Parameters related to soil constituents (organic matter, clay, silt, sand) varied moderately 
Table 3. Pearson's Correlation matrix for different soil parameters (bilateral test).

\begin{tabular}{|c|c|c|c|c|c|c|c|c|c|c|}
\hline & EMh & EMv & Ece & $\mathbf{P}^{\mathrm{H}}$ & OM & T.Limestone & $\begin{array}{c}\text { Humi- } \\
\text { dity }\end{array}$ & Clay & Silt & Sand \\
\hline EMh & 1 & & & & & & & & & \\
\hline EMv & $0.975^{* *}$ & 1 & & & & & & & & \\
\hline ECe & $0.896^{* *}$ & $0.852^{* *}$ & 1 & & & & & & & \\
\hline $\mathbf{P}^{\mathrm{H}}$ & $-0.351^{*}$ & -0.299 & $-0.348^{*}$ & 1 & & & & & & \\
\hline OM & $-0.642^{* *}$ & $-0.591^{* *}$ & $-0.627^{* *}$ & 0.250 & 1 & & & & & \\
\hline T.Limestone & -0.051 & 0.008 & -0.188 & -0.004 & -0.122 & 1 & & & & \\
\hline Humidity & $0.797^{* *}$ & $0.812^{* *}$ & $0.633^{* *}$ & $-0.369^{*}$ & $-0.492^{* *}$ & 0.033 & 1 & & & \\
\hline Clay & $0.621^{* *}$ & $0.624^{* *}$ & $0.589^{* *}$ & -0.306 & $-0.564^{* *}$ & -0.192 & $0.763^{* *}$ & 1 & & \\
\hline Silt & -0.174 & -0.178 & -0.239 & -0.333 & 0.218 & $0.358^{*}$ & -0.008 & -0.264 & 1 & \\
\hline Sand & $-0.510^{* *}$ & $-0.510^{* *}$ & $-0.441^{* *}$ & $0.494^{* *}$ & $0.428^{*}$ & -0.018 & $-0.745^{* *}$ & $-0.830^{* *}$ & -0.318 & 1 \\
\hline
\end{tabular}

${ }^{*}$ Correlation is significant at $P$ value $<0,01{ }^{*}$ Correlation is significant at $P$ value $<0,05$

Table 4. Statistical of soil EC calculated and different classes of soil salinity.

\begin{tabular}{|c|c|c|c|c|c|c|}
\hline & Parameters & EMv & \multicolumn{2}{|c|}{ EMh } & \multicolumn{2}{|c|}{ ECe $\left(\right.$ dS.m $\left.^{-1}\right)$ calculated } \\
\hline & Number & 260 & \multicolumn{2}{|c|}{260} & \multicolumn{2}{|c|}{260} \\
\hline & Min. & 44.00 & \multicolumn{2}{|c|}{30.00} & \multicolumn{2}{|c|}{3.21} \\
\hline & Max. & 796.00 & \multicolumn{2}{|c|}{691.00} & \multicolumn{2}{|c|}{26.55} \\
\hline & Average. & 330.12 & \multicolumn{2}{|c|}{253.39} & \multicolumn{2}{|c|}{11.10} \\
\hline & Std.Dev. & 213.32 & \multicolumn{2}{|c|}{173.01} & \multicolumn{2}{|c|}{6.11} \\
\hline & $\mathrm{CV} \%$ & 64.62 & \multicolumn{2}{|c|}{68.28} & \multicolumn{2}{|c|}{55.02} \\
\hline Depth $(\mathrm{cm})$ & Number & \multicolumn{5}{|c|}{ Classes of soil salinity (ECe en dS.m ${ }^{-1}$ ) calculated } \\
\hline \multirow{3}{*}{0 to 75} & \multirow{3}{*}{260} & $<2$ & 2 to 4 & 4 to 8 & 8 to 16 & 16 to 26 \\
\hline & & - & 20 & 92 & 87 & 61 \\
\hline & & $0.00 \%$ & $7.69 \%$ & $35.38 \%$ & $33.46 \%$ & $23.46 \%$ \\
\hline
\end{tabular}

in space. The average of the measurements of EMh was lower than that of EMv; the value of the ratio (EMh / EMv) was 0.77 $(\leq 1.05)$, which reflects a descending and leached profile with an increase in salinity at depth (Corwin, Rhoades, 1990; Nogués et al., 2006).

The distribution of the percentage fractions of the sieve analysis in the soil samples from 34 profiles (sand, silt and clay) on the texture triangle of United States Department of Agriculture (USDA) classed is illustrated in Fig. 3 and shows that $75 \%$ of the samples had a fine texture (clay and clay-loam).

\section{Correlation analysis}

The correlation results are shown in Table 3. This correlation allows to highlight the possible relationships between two soil parameters at a significance level $P<5 \%$. Table 3 reveals a very highly significant effect and a positive correlation $(0.589 \leq r \leq$ 0.975, $P<0.001)$ of EMh and ECe with EMv, \% moisture and clay. Numerous study results confirm these results obtained in our work (Nehmdahl, Greve, 2001; Bronson et al., 2005; Corwin, Lesch, 2005; Abdelhafid, 2010; Gacem, 2015). For organic matter, the correlation of $\mathrm{pH}$ and sand with EMh and ECe was negative and significant $(0.35 \leq r \leq 0.64)$ (Nolin et al., 2002; Corwin, Lesch, 2005).

\section{Estimation of ECe from EM measurements}

The calibration was based on the use of simple regression to find a statistical relationship between the EMh measurements and the mean values of ECe $(0-75 \mathrm{~cm})$. The correlation was performed at a $5 \%$ significance level, $P<0.05$. It resulted in the following linear relationship:

\section{$\mathrm{ECe}=0.0353^{\star} \mathrm{EMh}+2.1548$ with $r=0.90 ; P<0.001$}

The result of the descriptive statistical parameters of the ECe was calculated for a number of measurements of 260 points of EMh and the different classes of soil salinity (ECe calculated in $\mathrm{dS} / \mathrm{m}$ ) (Table 4) (USDA, 1954).

\section{Irrigation water quality}

The suitability of water for irrigation also depends on its chemical constituents and certain quality parameters. The results of chemical and calculated water parameters (SAR, TDS, TH, RSC, $\% \mathrm{Na}$ and PI) of water wells are presented in Table 5 . The average chemical composition of the main ions is of the order of $\mathrm{Na}>\mathrm{Mg}$ $>\mathrm{Ca}>\mathrm{K}$ and $\mathrm{Cl}>\mathrm{SO} 4>\mathrm{HCO} 3$, which means that the dominant chemical facies of the groundwater is that of sodium chloride 
Table 5. Statistical of various parameters in groundwater in the study area $(n=40)$.

\begin{tabular}{|c|c|c|c|c|c|c|c|c|}
\hline Parameter & $\mathbf{p}^{\mathrm{H}}$ & EC & TDS & TH & $\mathrm{Na}^{+}$ & $\mathrm{Ca}^{2+}$ & $\mathrm{Mg}^{2+}$ & $\mathbf{K}^{+}$ \\
\hline Min. & 7.0 & 2240.0 & 1433.6 & 93.1 & 9.6 & 0.4 & 0.4 & 0.0 \\
\hline Max. & 8.4 & 15500.0 & 9920.0 & 3084.5 & 100.0 & 22.9 & 48.1 & 2.7 \\
\hline Average. & 7.7 & 5989.8 & 3833.4 & 1053.0 & 46.3 & 6.2 & 14.9 & 0.6 \\
\hline Std.Dev. & 0.3 & 3203.1 & 2050.0 & 711.0 & 24.3 & 4.7 & 11.4 & 0.8 \\
\hline CV\% & 4.0 & 53.5 & 53.5 & 67.5 & 52.5 & 75.8 & 76.7 & 123.6 \\
\hline Parameter & $\mathrm{Cl}^{-}$ & $\mathrm{SO}^{2-}$ & $\mathrm{CO}^{2-}$ & $\mathrm{HCO}_{3}^{-}$ & SAR & RSC & $\mathrm{Na}$ & PI \\
\hline Min. & 10.0 & 1.5 & 0.0 & 0.2 & 6.5 & -60.7 & 47.3 & 47.4 \\
\hline Max. & 193.0 & 38.1 & 1.2 & 13.6 & 27.0 & 2.1 & 92.2 & 96.2 \\
\hline Average & 49.5 & 12.6 & 0.2 & 2.4 & 14.9 & -18.5 & 69.9 & 71.2 \\
\hline Std.Dev. & 35.2 & 8.5 & 0.2 & 2.8 & 5.8 & 14.1 & 9.3 & 9.7 \\
\hline CV\% & 71.2 & 67.8 & 103.1 & 119.9 & 39.0 & 76.1 & 13.3 & 13.7 \\
\hline
\end{tabular}

Unit: EC in ( $\mu \mathrm{S} / \mathrm{cm})$; All ions in (meq/l); TDS, TH et RSC in (mg/L); Na et PI en (\%).

Table 6. Pearson's correlation Matrix for the chemical constituents and water quality parameters $(n=40)$.

\begin{tabular}{|c|c|c|c|c|c|c|c|c|c|c|c|c|c|}
\hline & $\mathrm{pH}$ & EC & TDS & TH & $\mathrm{Na}+$ & $\mathrm{Ca}^{2+}$ & $\mathbf{M g}^{2+}$ & $\mathrm{K}+$ & $\mathrm{Cl}^{-}$ & $\mathrm{SO}_{4}{ }^{2-}$ & $\mathrm{CO}_{3}{ }^{2-}$ & $\mathrm{HCO}_{3}^{-}$ & SAR \\
\hline pH & 1 & & & & & & & & & & & & \\
\hline EC & -0.038 & 1 & & & & & & & & & & & \\
\hline TDS & -0.038 & $1.000^{* *}$ & 1 & & & & & & & & & & \\
\hline TH & 0.041 & $0.545^{* *}$ & $0.545^{* *}$ & 1 & & & & & & & & & \\
\hline $\mathrm{Na}^{+}$ & 0.160 & $0.793^{* *}$ & $0.793^{* *}$ & $0.733^{* *}$ & 1 & & & & & & & & \\
\hline $\mathrm{Ca}^{2+}$ & -0.112 & 0.266 & 0.266 & $0.702^{* *}$ & $0.583^{* *}$ & 1 & & & & & & & \\
\hline $\mathrm{Mg}^{2+}$ & 0.096 & $0.569^{* *}$ & $0.569^{* *}$ & $0.957^{* *}$ & $0.673^{* *}$ & $0.465^{* *}$ & 1 & & & & & & \\
\hline $\mathbf{K}^{+}$ & $0.337^{*}$ & 0.023 & 0.023 & $0.467^{* *}$ & $0.346^{*}$ & 0.302 & $0.458^{* *}$ & 1 & & & & & \\
\hline $\mathrm{Cl}^{-}$ & -0.078 & $0.854^{* *}$ & $0.854^{* *}$ & $0.547^{\star *}$ & $0.689^{* *}$ & $0.338^{\star}$ & $0.542^{\star \star}$ & 0.046 & 1 & & & & \\
\hline $\mathrm{SO}_{4}^{2-}$ & 0.028 & $0.455^{* *}$ & $0.455^{\star *}$ & 0.230 & $0.319^{*}$ & 0.059 & 0.261 & -0.132 & 0.185 & 1 & & & \\
\hline $\mathrm{CO}_{3}^{2-}$ & 0.062 & 0.147 & 0.147 & -0.008 & 0.119 & -0.220 & 0.079 & 0.009 & -0.035 & -0.083 & 1 & & \\
\hline $\mathrm{HCO}_{3}^{-}$ & -0.003 & 0.233 & 0.233 & 0.168 & 0.165 & -0.160 & 0.274 & 0.045 & 0.002 & -0.095 & $0.759^{\star \star}$ & 1 & \\
\hline SAR & 0.182 & $0.576^{* *}$ & $0.576^{* *}$ & 0.109 & $0.702^{* *}$ & 0.145 & 0.076 & 0.027 & $0.433^{\star *}$ & 0.258 & 0.107 & 0.031 & 1 \\
\hline
\end{tabular}

Notes: ** - Correlation is significant at $P$ value $<0,01,{ }^{*}$ - Correlation is significant at $P$ value $<0,05$.

(Table 5). The result showed that the $\mathrm{pH}$ of the water varied from 7.02 to 8.38 , neutral to moderately alkaline. The EC exceeded the permitted limit of $2500 \mu \mathrm{S} / \mathrm{cm}$ (Durand, 1958; Freeze and Cherry, 1979). TDS values varied from 1433 to $9920 \mathrm{mg} / \mathrm{l}$, while SAR varied from 6.51 to 26.96 .

\section{Correlation analysis}

The correlation matrix of different variables is given in Table 6 and shows that there were very strong positive correlations $(0.45$ $\leq r \leq 1.00)$ of the EC with TDS, $\mathrm{Cl}^{-}, \mathrm{Na}^{+}, \mathrm{Mg}^{2}, \mathrm{SAR}$ and $\mathrm{TH}$ and between $\mathrm{Na}$ with ions $\left(\mathrm{Mg}^{2+}, \mathrm{Ca}^{2+}, \mathrm{K}^{+}, \mathrm{Cl}^{-}\right.$and $\left.\mathrm{SO}_{4}{ }^{2-}\right)$ and $\mathrm{SAR}$ at a significance level of $\mathrm{P}<0.05$. There was a strong correlation between $\mathrm{CO}_{3}^{2-}$ and $\mathrm{HCO}_{3}$. Almost all ions showed a negative relationship with $\mathrm{pH}$.

TDS, SAR, Na\%, RSC, PI and salinity risk were used in this study to assess the suitability of water for crop irrigation in the study area (Table 7).

\section{Total dissolved solids}

The quality of irrigation water depends on the amount of dissolved salts. The classification of well water is presented in Table 7. The TDS ranged from 1434 to $9920 \mathrm{mg} / \mathrm{l}$ with an average of $3833 \mathrm{mg} / \mathrm{l}$. According to Davis and De Weist (1966), the water from 19 wells is considered suitable for irrigation (useful for irrigation), while the water from the remaining 21 wells is unfit for irrigation. But according to the classification of Freeze and Cherry (1979), all groundwater is unsuitable because the TDS is $>1000 \mathrm{mg} / \mathrm{l}$.

\section{Salinity hazard (EC)}

EC represents the general concentration of water-soluble ions classified according to the standards proposed by the US Salinity Laboratory staff (USSL) (Freeze, Cherry 1979). The classification of the salinity hazard of water for irrigation is indicated in Table 
Table 7. Classification of water for irrigation.

\begin{tabular}{|c|c|c|c|c|}
\hline Index / classification & Range & Suitability for irrigation & Samples $(n=40)$ & Reference \\
\hline \multirow{8}{*}{ TDS (mg/l) } & $<500$ & Desirable for drinking & - & \multirow{4}{*}{ Davis and DeWiest (1966) } \\
\hline & $500-1,000$ & Permissible for drinking & - & \\
\hline & $1000-3000$ & Useful for irrigation & 19 & \\
\hline & $>3000$ & Unfit for irrigation & 21 & \\
\hline & $<1000$ & Fresh & - & \multirow{4}{*}{ Freeze and Cherry (1979) } \\
\hline & $1000-10000$ & Brackish & 40 & \\
\hline & $10000-10000$ & Saline & - & \\
\hline & $>10000$ & Brine & - & \\
\hline \multirow{4}{*}{ SAR } & $<10$ & S1- Excellent & 12 & \multirow{4}{*}{ Richards (1954) } \\
\hline & $10-18$ & S2-Good & 13 & \\
\hline & $18-26$ & S3-Doubtful & 13 & \\
\hline & $>26$ & S4-Unsuitable & 02 & \\
\hline \multirow{4}{*}{$\begin{array}{l}\text { Salinity hazard (EC in } \\
(\mu \mathrm{S} / \mathrm{cm})\end{array}$} & $<250$ & C1- Excellent or low & - & \multirow{4}{*}{ Freeze and Cherry (1979) } \\
\hline & $250-750$ & C2- Good or medium & - & \\
\hline & $750-2250$ & C3- Permissible or high & 02 & \\
\hline & $>2250$ & C4- Unsuitable or very high & 38 & \\
\hline \multirow{3}{*}{ RSC (meq/l) } & $<1,25$ & Safe & 39 & \multirow{3}{*}{ Eaton (1950) } \\
\hline & $1,25-2,5$ & Moderate & 01 & \\
\hline & $>2,5$ & Unsuitable & - & \\
\hline \multirow{5}{*}{$\mathrm{Na} \%$} & $<20$ & Excellent & - & \multirow{5}{*}{ Wilcox (1955) } \\
\hline & $20-40$ & Good & - & \\
\hline & $40-60$ & Permissible & 04 & \\
\hline & $60-80$ & Doubtful & 30 & \\
\hline & $>80$ & Unsuitable & 06 & \\
\hline
\end{tabular}

7. The categories $\mathrm{C} 1$ and $\mathrm{C} 2$ are considered suitable for irrigation and category C3 is allowed, while C4 and category C5 (>5000 $\mu \mathrm{S} / \mathrm{cm}$, excessive salinity), added by Durand (1958), are unauthorised for irrigation. The results showed that all the samples (38 wells) are in salinity category C4 and C5 which are unfit for irrigation (Fig. 4), except two which are allowed with caution.

\section{Sodium adsorption ratio}

A high level of sodium in groundwater adsorbs to soil particles, thereby altering the properties of the soil and also reducing its permeability (Ayers, Bronson, 1975). According to Richards (1954), water with SAR values below 10 is considered excellent, $10-18$ is good, $18-26$ is poor and above 26 is unsuitable for irrigation (USDA, 1954). Table 7 shows that 12 wells with SAR values below 10 (S1) and 13 wells in category (S2) can be considered suitable for irrigation. The remaining 13 wells in category (S3) and 2 wells in type (S4) are unsuitable for irrigation. The Riverside diagram of USSL combining EC and SAR allows this risk to be distinguished (Richards, 1954). The evaluation of water for irrigation purposes highlights four salinity hazard categories $(\mathrm{C} 1-$ $\mathrm{C} 4)$ and 4 sodium hazard categories (S1-S4) as shown in Fig. 4. The wells are distributed as follows: C3S3 (1 well), C4S2 (2 wells), C4S3 (12 wells), C4S4 (25 wells).

With reference to the interpretation of the categories corresponding to the saline and alkaline risk sections, we can make the following observations:

- $\quad$ C3S3 and C4-S2: water with a high salinity hazard and me- dium alkalinity. It is poor-quality water and is to be used with great care only in well-drained soils and for plants tolerant to salinity and leaching;

- C4-S3: water of very poor quality; to be used only in exceptional circumstances and

- C4-S4: water unsuitable for irrigation.

\section{Sodium percent (Na\%)}

Sodium is considered as an important parameter in irrigation water because it decreases soil fertility in a dry climate and poor drainage prevented by strong evaporation (Richards, 1954). According to Table 7, Wilcox's (1955) classification suggests that the water from 40 wells can be divided into three categories: 4 permissible (10\%), 30 doubtful (75\%) and 6 unsuitable (15\%). The combination of EC and \%Na allowed us to develop Wilcox's (1955) diagram. From this diagram, it can be seen that well water is classified from doubtful to unsuitable for irrigation (Fig. $5)$.

\section{Residual sodium carbonate}

It refers to residual alkalinity. A high RSC value leads to an increase in the adsorption of $\mathrm{Na}^{+}$in the soil, which reduces soil permeability and does not promote plant growth (Rao, 2012). The classification of water on the basis of RSC is given in Table 7 . Water with CSR RSC values $<1.25 \mathrm{meq} / \mathrm{l}$ is classified as suitable for irrigation. 


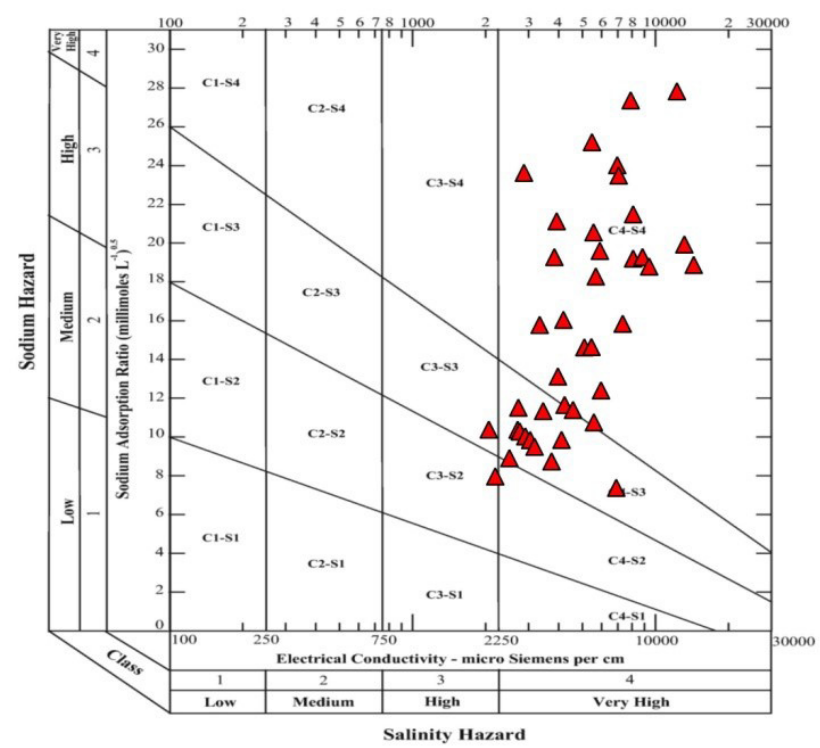

Fig. 4. Suitability of water irrigation based on EC and SAR - Richards (1954).

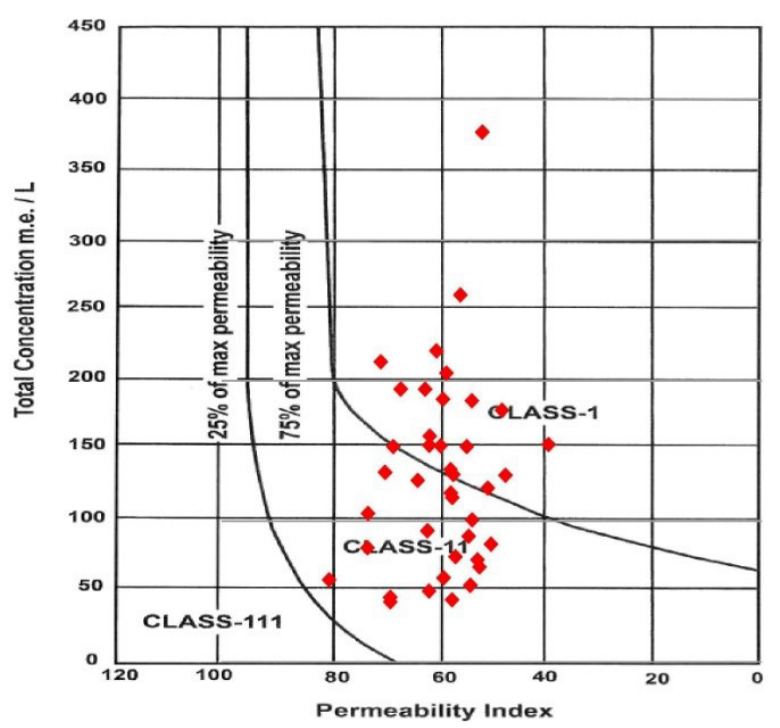

Fig. 6. Suitability of water for irrigation based on PI and total concentration of ions Doneen (1964).

\section{Permeability index}

The PI is an indicator of the suitability of water for irrigation. Long-term use of irrigation water with high salt concentration has adverse effects on soil permeability. According to Doneen (1964), PI is classified into three categories: class I (>75\%, water is good for irrigation), class II $(25 \%-75 \%$, water is acceptable under certain conditions) and class III ( $<25 \%$, water is no longer usable). Class I and II water is recommended for irrigation. The combination of PI (\%) and total concentration (meq/l) allowed

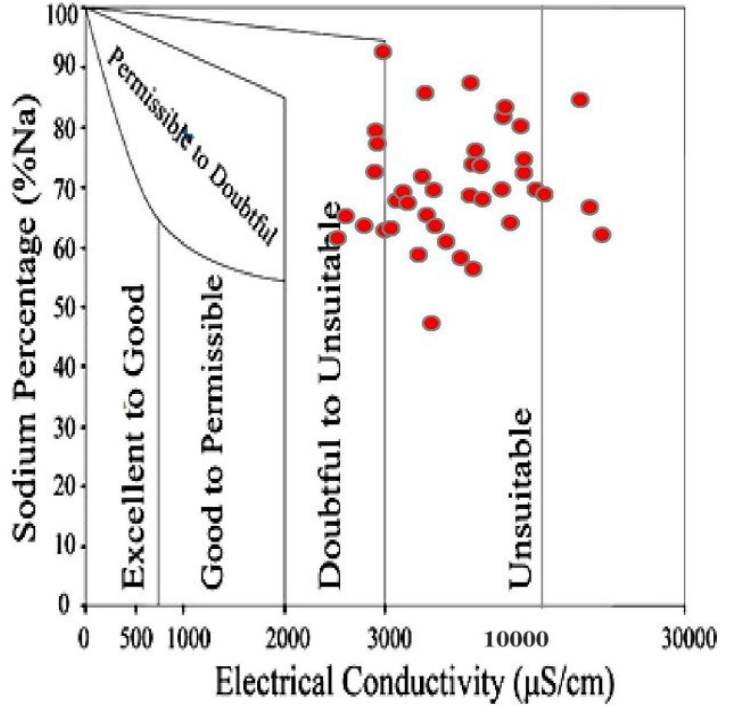

Fig. 5. Suitability of water for irrigation based on EC and $\mathrm{Na} \% \mathrm{Wil}-$ $\operatorname{cox}(1955)$.

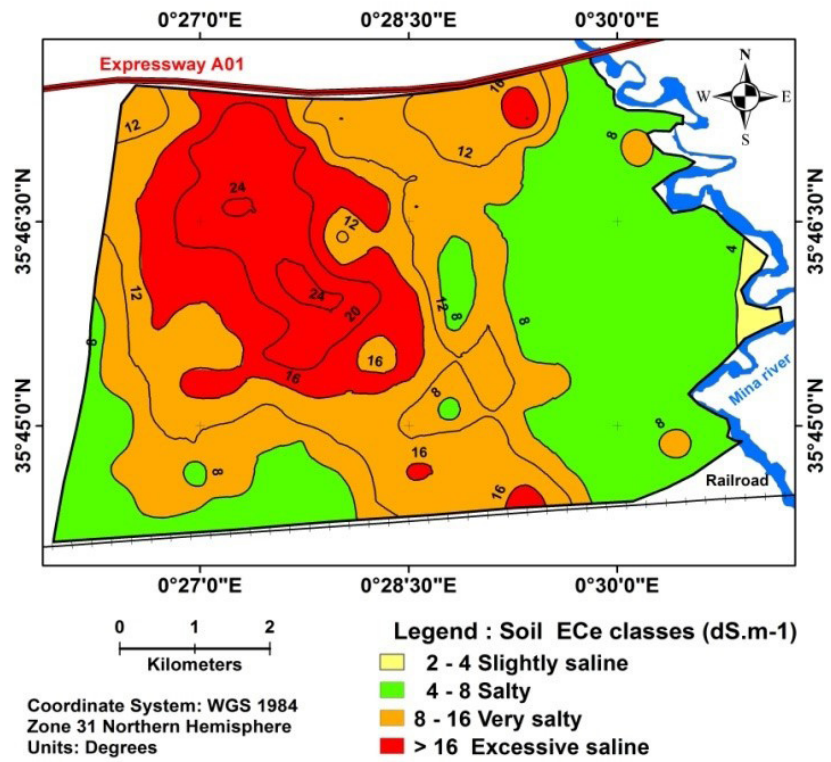

Fig. 7. Spatial distribution map of soil Salinity (ECe).

us to elaborate Doneen's diagram (1964). It showed that water could be classified as: class I 50\% and class II 50\% (Fig. 6).

\section{Soil and irrigation water salinity risk mapping}

OK interpolation consists of predicting and mapping of the estimated spatial variation of ECe values at the 260 EMh measurement locations using simple regressions at sampled and non-sampled locations. Analysis of the isovalues map of the ECe established by the OK (Fig. 7) shows some heterogeneity in sa- 


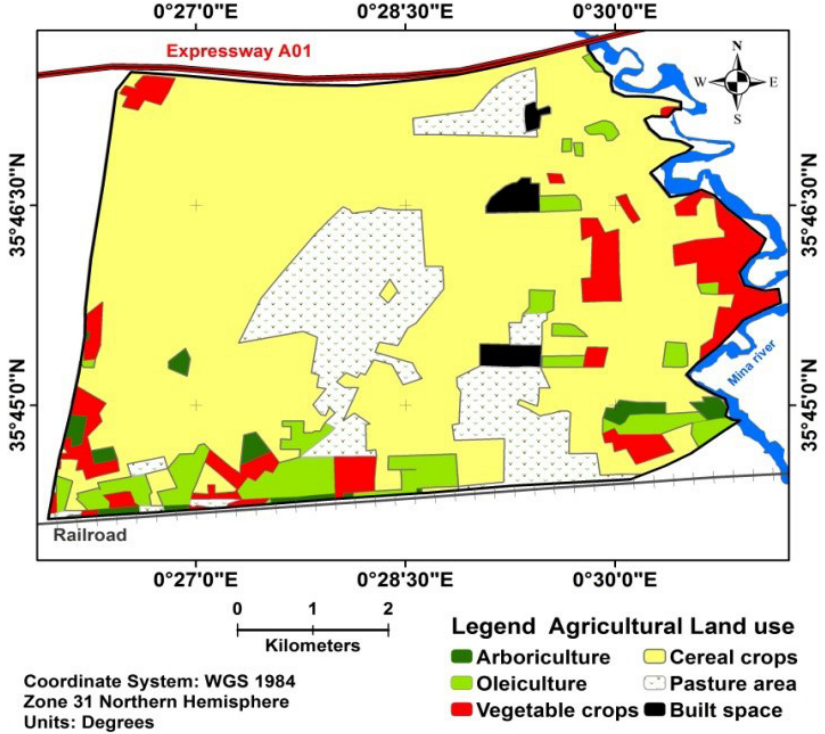

Fig. 8. Agricultural land cover map.

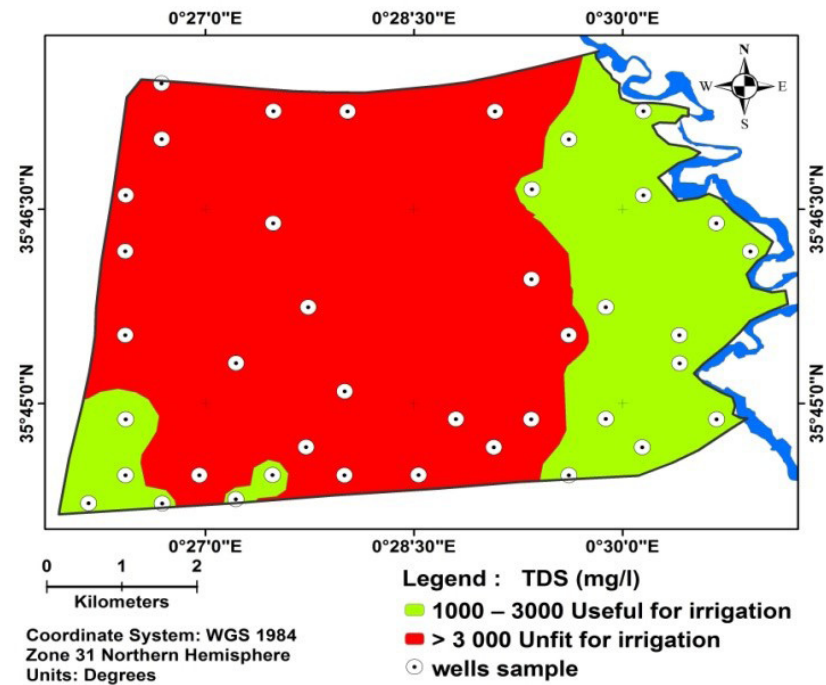

Fig. 10. Spatial distribution map of TDS.

linity at the area of study. A very highly significant correlation ( $r$ $=0.90 ; P<0.001$ ) between measured and estimated ECe values showed good estimate of the ECe by the kriging regression, referring to the interpretation standards of the USDA (1954).

Slightly saline soils ( $2 \mathrm{dS} / \mathrm{m}<\mathrm{ECe}<4 \mathrm{dS} / \mathrm{m}$ ) occupy a small area of 31 ha and are located at the extreme eastern point of the study area bordering Mina wadi. The saline soils $(4 \mathrm{dS} / \mathrm{m}<\mathrm{ECe}$ $<8 \mathrm{dS} / \mathrm{m}$ ) are fairly well represented (1360 ha, i.e. $34.8 \%)$ and are spread out along Mina wadi and a part of it in the southwest. These values of ECe $(<8 \mathrm{dS} / \mathrm{m})$ decrease towards the watercourse (Mina wadi) where the drainage network exists and functions. The very saline soils $(8 \mathrm{dS} / \mathrm{m}<\mathrm{ECe}<16 \mathrm{dS} / \mathrm{m})$ oc-

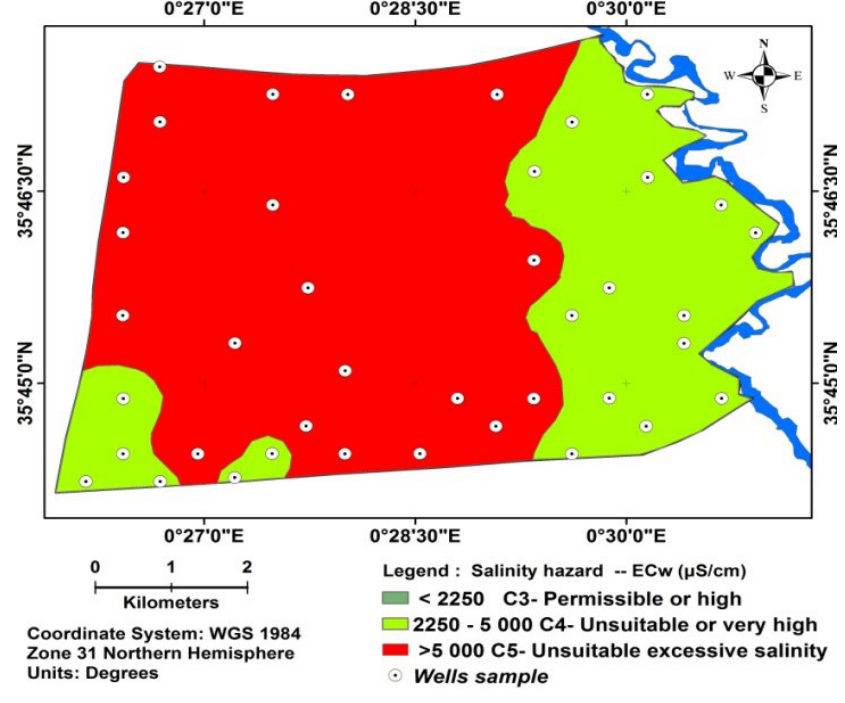

Fig. 9. Spatial distribution map of Salinity hazard (EC).

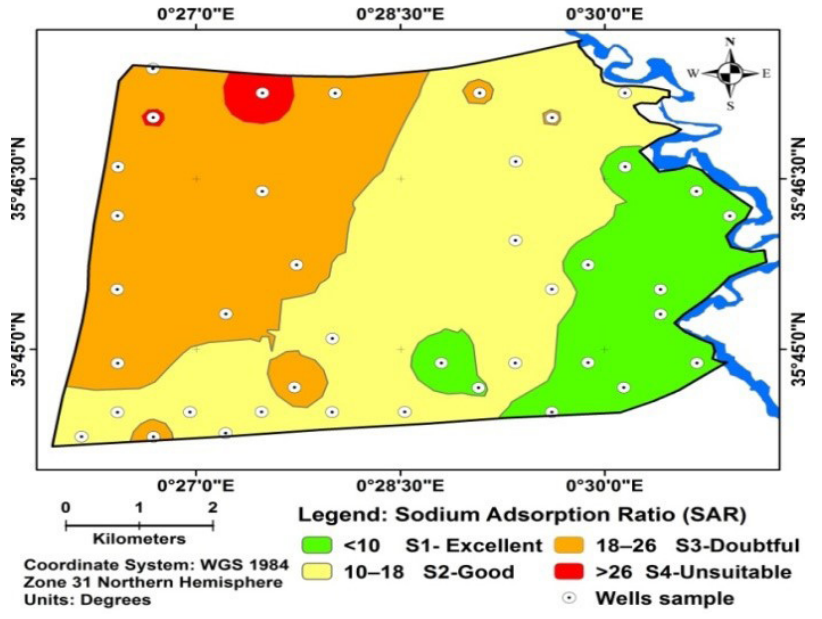

Fig. 11. Spatial distribution map of SAR.

cupy a large area (42\%) and are spatially distributed from the south (limit with the railway) and grow towards the northwest which is limited to the north by the East-West expressway (A01). Extremely saline soils $(16 \mathrm{dS} / \mathrm{m}<\mathrm{ECe}<27 \mathrm{dS} / \mathrm{m})$ represent $22.4 \%$ and are centrally located in the northwestern part of the area of study.

We also noticed that highly saline and extremely saline soils are located in the agricultural plots abandoned by farmers due to their degradation or irrigation with too salty surface water $(>5000 \mu \mathrm{S} / \mathrm{cm})$ and a defective drainage network; the expressway can be also a barrier for the drainage of excess water and consequently the leaching of salts in the rainy or irrigation period. 


\section{Agricultural land use according to salinity classes}

The distribution of land use of the agricultural space composed of different plant species has been classified according to the different levels of salinity that we have defined and the dangers that salinity can present on the sustainability of agricultural systems. The different classes of agricultural land use are shown in Fig. 8.

Cereal crops, dominated by barley, covered an area of 2650 ha or $67 \%$ associated with rangelands and were distributed over all salinity levels (4-27 dS/m). Vegetable growing occupied $7.3 \%$, artichoke and watermelon were predominant and others were interspersed under fruit trees $(2<\mathrm{ECe}<16 \mathrm{dS} / \mathrm{m})$. The arboriculture was characterised by fruit tree species: citrus and pomegranate occupied 64 ha $(1.62 \%)$. These orchards were located in saline soils $(4<\mathrm{ECe}<16 \mathrm{dS} / \mathrm{m})$. As for olives, they were distributed on saline soils ( $4<\mathrm{ECe}<16 \mathrm{dS} / \mathrm{m}$ ) occupying 250 ha $(6.32 \%)$; they were represented by olive groves and other olive plantations scattered in a few agricultural plots. The pasture area witch covered 616 ha $(15.8 \%)$, which was characterised by halophytic vegetation (Salsola, Atriplex) covering a layer of salts. Among these species were Atriplex halimus L. and A. mauritanica B., Sueda fruticosa F. and Plantago psyllium F. In addition, there was also spontaneous vegetation (Phragmites), which needed the humidity of the subsoil. These halophytic plant species were localised in poorly drained soils with a salinity level of $8-27 \mathrm{dS} / \mathrm{m}$ in the central and northern parts of the area of study. Under homogeneous self-ecological conditions, plant species with higher salinity tolerance will lead to higher salinisation than salt-intolerant species (Daoudi, Sitayeb, 2020).

\section{Spatial interpolation of parameters by IDW}

The IDW method consists of mapping the spatial variation of ECw, SAR and TDS values in 40 well water samples. Maps of the spatial distribution of ECw and TDS in surface water is shown in Figs 9 and 10 and they show too high levels of ECw and TDS unsuitable for irrigation and occupying a large catchment area (70\% of the study area); thus, ECw is classified as C5 (>5000 $\mu \mathrm{S} / \mathrm{cm}$, unsuitable excessive salinity). Also, with regard to TDS (>3000 mg/l, unfit for irrigation), it was distributed from the centre of the southern part to the northern part. Too high salt and salinity levels in well water can be related to the influence of poor salt drainage, groundwater circulation and the presence of saline rock layer. These values decrease towards the east due to the influence of the Mina valley through renewal of groundwater with the supply of less-saline watercourses. The spatial distribution map of the SAR (Fig. 11) shows higher values in wells located in the northwestern part of the study area (high concentration of sodium) and lower values at the Mina wadi side.

\section{Conclusion}

This work was carried out for the assessment and mapping of the risk of soil salinity and quality of groundwater used for irrigation in Mina plain in the northwest of Algeria. The evaluation and mapping of soil salinity using EM38 showed a high level of risk of soil salinity, with $90 \%$ of the study area having a salinity of ECe $>4 \mathrm{dS} / \mathrm{m}$, of which $65 \%$ showed a very saline to extremely saline level $(\mathrm{ECe}>8 \mathrm{dS} / \mathrm{m})$. As for the evaluation of the quality of the groundwater used for irrigation purposes, out of 40 wells analysed, 12 wells were classified as C4S3 (very poor quality water) and 25 wells as C4S4 (water unsuitable for irrigation). The analyses also showed excessively high levels of EC and TDS unfit for irrigation (70\% of the study area) and higher SAR values in wells located in the northwestern part of the study area (high sodium concentration and percentage). The results obtained showed that the problem of salinity for irrigated agriculture has two aspects: a potential risk when water rich in sodium is used for irrigation, which can affect the physical properties of the soil in the long term following the use of water of medium to poor quality and a major constraint when salinity levels have reached a level high enough to affect agricultural yields, and the risk against the sustainability of natural and cultivated plant species. We can consider this work as well as a contribution of highlights the need for a strategy to control soil salinity due to irrigation by saline groundwater. In practice, these are not irreversible constraints or unavoidable risks; only farmers need to adapt their agricultural practices to these constraints and risks in order to increase soil productivity and, consequently, crop yields. Finally, the action consists in implementing good agricultural practices (choice of tolerant crop species, mulching of land to conserve soil moisture), efficient use of water through rational irrigation, and appropriate drainage to leach salts and control surplus water discharges to avoid soil, water and environmental pollution.

\section{References}

Abdelhafid, Y. (2010). Soil salinity mapping by electromagnetic induction: Case of the eastern zone of the irrigated perimeter of the Mina. Magister thesis in Agronomy, ENSA, Algiers.

ANRH (2003). Monitoring and modeling of soil salinity in the irrigated perimeter of the Mina.

APHA (1995). Standard methods for the examination for water and wastewater. Washington: Byrd Press Springfield.

Ayers, R. \& Bronson S. (1975). Guidelines for interpretation of water quality for agriculture. Davis: University of California.

Bronson, K.F., Booker, J.D., Officer, S.J., Lascano, R.J., Mass, S.J., Searcy, S.W. \& Booker J. (2005). Apparent electrical conductivity, soil properties and spatial covariance in the U.S. southern high plains. Precision Agriculture, 6, 297-311. DOI: 10.1007/s11119-005-1388-6.

Brown, E., Skougstad, M.W. \& Fishman M.J. (1970). Techniques of water resources Investigations. Washington: US Government Printing Office.

Burrough, P.A. \& McDonnell R.A. (1998). Principles of geographical information systems. Oxford: Oxford University Press.

Cameron, D.R., Read, D.W.L., De Jong, E. \& Oosterveld M. (1981). Mapping salinity using resistivity and electromagnetic inductive techniques. Can. J. Soil Sci., 61(1), 67-78. DOI: 10.4141/cjss81-008.

Corwin, D.L. \& Lesch S.M. (2005). Apparent soil electrical conductivity measurements in agriculture. Comput. Electron. Agric., 46(1-3), 11-43. DOI: 10.1016/j.compag.2004.10.005.

Corwin, D.L. \& Rhoades J.D. (1990). Establishing soil electrical conductivity - Depth relations from electromagnetic induction measurements. Commun. Soil Sci. Plant Anal., 21(11), 861-901. DOI:10.1080/00103629009368275.

Daoud, Y. \& Halitim A. (1994). Irrigation and salinization in the Algerian Sahara. Drought.

Daoudi, K. \& Sitayeb T. (2020). Effects of land use changes on the soil physicochemical properties in south-western Algeria. Ekológia (Bratislava), 39(3), 224-235. DOI: 10.2478/eko-2020-0017.

Davis, S.N. \& De Weist R.J.M. (1966). Hydrogeology. New York: John Wiley and Sons.

Djili, K. (2000). Contribution to the knowledge of soils in Northern Algeria. Doctoral Thesis, INA, Algiers. 
Doneen, L.D. (1964). Water quality for Agriculture, Department of Irrigation. Davis: University of California.

Douaoui, A.E.K. \& Hartani T. (2007). Impact de lirrigation par les eaux souterraines sur la dégradation des sols de la plaine du Bas-Chéliff. Actes du troisième atelier régional du projet Sirma, Nabeul, Tunisie.

Durand, J.H. (1958). Irrigable soils. Soil study. Imbert, Algiers.

Eaton, F.M. (1950). Significance of carbonates in irrigation waters. Soil Sci. $69,123-133$.

FAO (2006). Electronic conference on salinization. Extension of salinization and rehabilitation strategies. Organized and coordinated by International Program for Technology and Research in Irrigation and Drainage, from February 6 to March 6, 2006

Freeze, R.A. \& Cherry J.A. (1979). Groundwater. New Jersey: Prentice Hall Inc.

Gacem, F. (2015). Spatial and temporal study of the salinity in the soils of the plain of Mina (Relizane). Magister thesis in biology, University of Mostaganem.

Gaucher, G. \& Burdin S. (1974). Geology, geomorphology and hydrology of the salted lands: Contribution to salted lands enhancement. France University Press.

Halitim, A. (1985). Contribution to the study of soils in arid zones (High Steppe Plains of Algeria). Morphology, distribution and role of salts in the genesis and behavior of soils. State Doctorate thesis, University of Rennes.

Hem, J.D. (1985). Study and interpretation of the chemical characteristic of natural water. Charlottesville: University of Virginia.

INSID (2008). Saline soils in Algeria. NISID.

Job, J.O., Hachicha, M. \& Loyer J.Y. (1990). Electromagnetic conductivity and mapping of soil salinity. ORSTOM.

Legros, J.P. (2009). Land salinization around the world. Montpellier: Academy of Sciences and Letters. http://academie.biu-montpellier.fr/

Lesch, S.M., Strauss, D.J. \& Rhoades J.D. (1995). Spatial prediction of soil salinity using electromagnetic induction techniques: I. Statistical predictions models: a comparison of multiple linear regression and co-kriging. Water Resources Research, 31, 373-386. DOI: 10.1029/94WR02179.

Nehmdahl, H. \& Greve M.H. (2001). Using soil electrical conductivity measurements for delineating management zones on highly variable soils in Denmark. In G. Grenier \& S. Blackmore (Eds.), Third European Conference on Precision Agriculture (pp. 461-466). Montpellier: Agro Montpellier.
Nogués, J., Robinson, D.A. \& Herrero J. (2006). Incorporation electromagnetic induction methods into regional soil salinity survey of irrigation districts. Soil Sci. Soc. Am. J., 70(6), 2075-2085. DOI: 10.2136/sssaj2005.0405.

Nolin, M.C., Gagnon, B., Leclerc, M.L., Cambouris, A.N., Bélanger, G. \& Simard R.R. (2002). Influence of pedodiversity and land uses on the within-field spatial variability of selected soil and forage quality indicators. In P.C. Robert (Ed.), Proceedings of the $6^{\text {th }}$ international conference on precision agriculture and other precision resources management (pp. 181-197). Minnesota: University of Minnesota.

Rao, N.S., Subrahmanyam, A., Kumar, S.R., Srinivasulu, N., Rao, G.B., Rao, P.S. \& Reddy G.V. (2012). Geochemistry and quality of groundwater of Gummanampadu sub-basin, Guntur district, Andhra Pradesh, India. Environmental Earth Sciences, 67(5), 1451-1471. DOI: 10.1007/s12665012-1590-6.

Richards, L.A. (Ed.) (1954). Diagnosis and improvement of saline and alkali soils. Washington: USDA.

Szabolcs, I. (1989). Salt-affected soils. Boca Raton: CRC Press.

Triantafilis, J., Odeh, I.O.A. \& McBratney A.B. (2001). Five geostatistical models to predict soil salinity from electromagnetic induction data across irrigated cotton Soil Sci. Soc. Am. J., 65(3), 869-878. DOI: 10.2136/ sssaj2001.653869x.

USDA (1954). Diagnosis and improvement of saline and alkali soils. Washington: U.S. Salinity Laboratory Staff, Government Printing Office.

USGS earth explorer: https://earthexplorer.usgs.gov/

Vlotman, W.F. (2000). Calibrating the EM38. EM38 Workshop, New Delhi, India.

Walter, C. (1990). Estimation of soil properties and quantification of their variability at medium scale: soil and geostatistical mapping in the south of Ile et vilaine (France). Doctoral thesis, University of Paris.

Wilcox, L.V. (1955). Classification and use of irrigation waters. Washington: USDA. World Geodetic System (1984). National Geospatial-Intelligence Agency. 